\title{
Effects of Oral Environment Stabilization Procedures on Streptococcus mutans Counts in Pregnant Women
}

\author{
Flavia Cristina VOLPATO ${ }^{1}$ \\ Fabiano JEREMIAS ${ }^{2}$ \\ Denise Madalena Palomari SPOLIDÓRIO ${ }^{3}$ \\ Silvio Rocha Corrêa da SILVA ${ }^{1}$ \\ Aylton VALSECKI JUNIOR ${ }^{1}$ \\ Fernanda Lopez ROSELL ${ }^{1}$
}

\begin{abstract}
${ }^{1}$ Department of Community Dentistry, ${ }^{2}$ Department of Pediatric Dentistry and Orthodontics, ${ }^{3}$ Department of Physiology and Pathology, Araraquara Dental School, UNESP - Univ. Estadual Paulista, Araraquara, SP, Brazil
\end{abstract}

\begin{abstract}
The aim of this study was to determine the effect of oral environment stabilization (OES) on the counting of Streptococcus mutans in high-caries-risk pregnant women participants of a prevention program in a public teaching institution. The sample was composed of 30 pregnant women aged 18 to 43 years, who looked for treatment at the Preventive Dentistry Clinic of the Araraquara Dental School, UNESP. Saliva samples were collected before and after the OES procedures and were forwarded to the pathology for observation and quantification of $S$. mutans CFU. There was a decrease in the number of $S$. mutans $C F U$, which was significantly different ( $<<0.0001)$ between samples. Considering the age group, $70.0 \%$ were between 18 to 30 years old and $30.0 \%$ belonged to the $31-43$-year-old age group. Data related to the pregnancy period showed that $73.4 \%$ were in the second trimester, $13.3 \%$ in the first and $13.3 \%$ in third trimester. OES showed to be an effective clinical procedure in diminishing the number of $S$. mutans CFU in the saliva of high-cariesrisk pregnant women. This management is simple and effective, corresponding to the basic treatment needs of pregnant women that search dental care in this public service.
\end{abstract}

Key Words: Streptococcus mutans, pregnant women, disease prevention, oral environment stabilization.

\section{INTRODUCTION}

The idea that dental caries is transmissible was first demonstrated by Keyes (1) in 1960, and the vertical mother-child relationship of this transmissibility has been emphasized through the years.

Mothers frequently have an intimate contact with their children during the first two years of their life. It is believed that it is in this period that Streptococcus mutans are initially transferred, in such a way that the maternal salivary levels guide the colonization and the disease extension in their children (2). According to Hanada (3), the reduction of microbial levels in highly infected mother's saliva can inhibit or retard their establishment in mouth of their children.
The principle of Oral Health Promotion shows, among other principles, that the dental caries must be prevented and health must be promoted aiming at the individual as a whole. One of the main and initial clinical procedures in this philosophy of treatment is the oral environment stabilization, a conjunct of techniques that control the quantity and quality of oral microbiota. Elimination of pathogen focuses and control of risk of caries disease progression are aimed by means of mass excavation of carious tissue, sealing of cavities with a temporary material and extraction of residual roots. This way, oral environment stabilization (OES) propitiates the establishment of a functional dental care plan, strengthening of dental structure, an intra-canalicular bacteriostatic action and the control of intra-personal 
transmissibility risk. In this context, the aim of this study was determine the number of colony forming units (CFU) of S. mutans in high-caries-risk pregnant women of a prevention program in a public teaching institution, before and after oral environment stabilization.

\section{MATERIAL AND METHODS}

The present study was approved by the Research Ethics Committee of the Araraquara Dental School UNESP (ADS-UNESP; Protocol number 56/04).

\section{Study Population}

The study population comprised all pregnant women that received dental care between October 2006 and October 2008 at the Clinic of Preventive Dentistry of ASD-UNESP, a University Teaching Unit with cooperation with the Brazilian Public Health System - SUS. Among the 73 pregnant women enrolled in the study, 30 met all inclusion criteria for participation in the study: high caries risk; age over 18 years; no systemic diseases such as hypertension, diabetes or heart disease; no complications during pregnancy; giving birth after the end of the study.

\section{Material Collection and Transportation}

Before the beginning of the dental treatment, saliva was collected (first collection) in a sterile, thread sealing, glass tube (Vidrolabor, São Paulo, SP, Brazil) during 1 min until a sufficient amount $(1.0 \mathrm{~mL})$ was obtained for laboratory analysis. Samples were collected and maintained on ice during all collection period and were transported to the Pathology Laboratory, not exceeding a 4-h period (considering the beginning of collection) (4). After 1 week from the end of environment stabilization, the second collection was realized, following the same steps of the first collection.

\section{Material Processing}

Tubes containing saliva were vortexed for 30 (Vortex AP-56; Marconi Laboratory Equipment Inc., Piracicaba, SP, Brazil) to obtain a uniform suspension (homogenization). Next, the saliva was diluted in $10^{-1}$ to $10^{-4}$ decimal series in a $0.05 \mathrm{M}$ phosphate buffer, $\mathrm{pH}$ 7.3 (dilution) (5). For S. mutans cultivation (material sowing), aliquots of $25 \mu \mathrm{L}$ from each dilution were inoculated in duplicate in Petri dishes (Jprolab, São José dos Pinhais, PR, Brazil) containing Sucrose Bacitracin $\operatorname{agar}\left(\mathrm{SB}_{20}\right)$ (Acumedia; Neogen, Lansing, MI, USA) (6) and incubated for $48 \mathrm{~h}$ at $37^{\circ} \mathrm{C}$ in anaerobiosis, using the GasPak (BBL) (Voigt Global Distribution Inc., Lawrence, Kansas, USA) system. Colonies of S. mutans were counted with an electronic digital colony counter (Modelo CP-602; Phoenix, Araraquara, SP, Brazil).

\section{S. mutans Identification}

The observation and counting of colonies (colonial morphology) with features belonging to $S$. mutans was performed under reflecting light with a stereomicroscope (Carl Zeiss, Jena, Germany), following the standards described for the $\mathrm{SB}_{20}$ environment $(6,7)$.

\section{Oral Environment Stabilization}

Pregnant women identified as high-caries-risk individuals were subjected to the second saliva collection followed by an OES protocol that included: a) mass excavation: curettage of softened carious tissue with appropriate-sized dentin excavators, under relative isolation, followed by cavity washing with water-air spray, drying and sealing with conventional glass ionomer (Vidrion R) (SSWhite, Rio de Janeiro, RJ, Brazil); b) extraction: extraction of residual roots when no other intervention was possible for these teeth.

Data were analyzed statistically using the software InStat (GraphPad Software, Inc. La Jolla, CA, USA). The amount obtained from saliva samples before (s0) and after (s1) OES were tested regarding their normal distribution using the Kolmogorov-Smirnov test $(p<0.05)$ and as their normality could not be verified, both groups were compared with the non-parametric Wilcoxon test $(\mathrm{p}<0.05)$.

\section{RESULTS}

There was a decrease in $S$. mutans CFU counts, with a statistically significant difference $(\mathrm{p}<0.0001)$, between pregnant women's saliva samples before ( $\mathrm{s} 0)$ and after (s1) OES (Table 1).

Seventy percent of the pregnant women that looked for assistance at the "Dental Attention in Antenatal and Postnatal Program" supported by the discipline of Preventive and Community Dentistry of ASD-UNESP were aged 18 to 30 years, an age range 
considered the most reproducible in women, mainly in primigravids. Thirty percent of the women belonged to the 31-43-year-old age group, when women usually had already had at least one child.

Considering the gestational trimester, $13.3 \%$ of pregnant women were in the first (from 1 to 3 months of gestation), $73.4 \%$ were in the second (from 4 to 6 months of gestation) and $13.3 \%$ were in the third (from 7 to 9 months of gestation).

\section{DISCUSSION}

The Brazilian Public Health System (SUS), in special the oral health system, is suffering a period of transition of a strictly social model to a preventive model that promotes oral health. This later involves all the life cycles. As the main problem of the oral health in Brazil is dental caries, it is of great interest to public health and dentistry that high-caries-risk individuals or groups of them are identified, since the costs with prevention can be remarkably reduced, increasing the efficiency in preventive treatment plans (8).

Some of the etiologic factors of caries disease that

Table 1. Number of $S$. mutans $\mathrm{CFU} / \mathrm{mL}$ in the saliva before ( $\mathrm{s} 0$ ) and after (s1) oral environment stabilization in high-caries-risk pregnant women. Araraquara, SP, Brazil, 2008.

\begin{tabular}{cccccc}
\hline Women & CFU s0* & CFU s1* & Women & CFU s0* & CFU s ${ }^{*}$ \\
\hline 1 & $1.44 \times 10^{7}$ & $2.00 \times 10^{5}$ & 16 & $5.28 \times 10^{5}$ & $4.80 \times 10^{3}$ \\
2 & $4.48 \times 10^{4}$ & $4.00 \times 10^{3}$ & 17 & $6.72 \times 10^{7}$ & $3.00 \times 10^{3}$ \\
3 & $2.60 \times 10^{4}$ & 0.00 & 18 & $2.62 \times 10^{5}$ & $2.00 \times 10^{3}$ \\
4 & $1.92 \times 10^{5}$ & $4.60 \times 10^{4}$ & 19 & $1.72 \times 10^{5}$ & $4.00 \times 10^{3}$ \\
5 & $1.8 \times 10^{6}$ & $4.00 \times 10^{4}$ & 20 & $1.40 \times 10^{7}$ & $2.00 \times 10^{3}$ \\
6 & $6.3 \times 10^{5}$ & $3.60 \times 10^{5}$ & 21 & $1.00 \times 10^{6}$ & $1.00 \times 10^{3}$ \\
7 & $1.20 \times 10^{5}$ & $1.60 \times 10^{4}$ & 22 & $5.03 \times 10^{5}$ & $5.00 \times 10^{3}$ \\
8 & $5.20 \times 10^{4}$ & $1.30 \times 10^{4}$ & 23 & $1.48 \times 10^{5}$ & $3.00 \times 10^{3}$ \\
9 & $3.20 \times 10^{5}$ & $4.20 \times 10^{4}$ & 24 & $2.50 \times 10^{6}$ & $2.00 \times 10^{2}$ \\
10 & $1.32 \times 10^{6}$ & $2.48 \times 10^{4}$ & 25 & $2.62 \times 10^{5}$ & $5.00 \times 10^{3}$ \\
11 & $1.92 \times 10^{5}$ & $3.20 \times 10^{3}$ & 26 & $5.02 \times 10^{5}$ & $3.30 \times 10^{3}$ \\
12 & $2.62 \times 10^{5}$ & $4.00 \times 10^{3}$ & 27 & $6.80 \times 10^{5}$ & $3.50 \times 10^{4}$ \\
13 & $4.92 \times 10^{6}$ & $4.00 \times 10^{2}$ & 28 & $1.30 \times 10^{5}$ & $4.50 \times 10^{3}$ \\
14 & $1.00 \times 10^{6}$ & $7.70 \times 10^{5}$ & 29 & $2.72 \times 10^{6}$ & $3.40 \times 10^{3}$ \\
15 & $1.80 \times 10^{5}$ & $7.60 \times 10^{4}$ & 30 & $6.80 \times 10^{5}$ & $2.10 \times 10^{3}$ \\
\hline
\end{tabular}

*Statistically significant, Wilcoxon test $(\mathrm{p}<0.0001)$. define an individual as being at high risk are the counts of cariogenic microorganisms, mainly $S$. mutans, and the potential of transmissibility from mothers to their children. Microbiological and molecular evaluations suggest that pregnant women are a high risk group for caries development (9).

This transmissibility occurs due to a large number of $S$. mutans in maternal saliva that get in contact with children before eruption of their teeth $(10,11)$. Thus, mothers with high or low levels of $S$. mutans tend to have children with the same salivary levels of this microorganism $(6,12)$. Studies have demonstrated that preventive care measures in pregnant women or mother with young children have resulted in reduction in $S$. mutans levels in the mothers and decrease in colonization of these microorganisms and caries development in their children (13). Berkowitz (14) believes that the main proposal should be avoiding, as earlier as possible, the transmission of $S$. mutans from mother, father or other individuals that get in contact with the child. It is recommended not only the determination of the level of infection in pregnant woman, but also oral care to reduce the number of cariogenic bacteria and the risk of transmission together with information about these microorganisms transmission modes and caries prevention methods. In the present study, $73.4 \%$ of pregnant women were between 4 and 6 months of gestation. It is important to note that, clinically, the second trimester is the most indicated for dental treatment, in which pregnant women do not have so much nausea and other physiological alterations, being the most stable trimester. On the other hand, in the first trimester, complaints about nausea are more frequent and the embryo is being implanted in the uterus walls, increasing the susceptibility of abortion 
and bad embryo formations. In the third trimester it is common the reduction of blood circulation and respiratory difficulty, due to the gravid uterus weigh, which causes great discomfort to the pregnant woman. It does not mean, however, that the dental treatment cannot be performed in the first and third trimesters. Is must be considered the risk of gestation and the well-being of pregnant woman in order to plan the treatment need.

Considering the conditions described above, we was aimed at intervening in these situations by establishing efficient, effective and fast preventive measures that could contribute to pain resolution with recovery of functionality, mainly during chewing, and to the reduction of $S$. mutans counts in the oral cavity of the studied group of pregnant women, preventing transmissibility to their children. In the same way as discussed in the present study, Rego et al. (15) and Signoretto et al. (16) stated that the control of patient's caries activity should be the initial step in a restorative treatment and therefore basic procedures, such as the OES, are necessary to reduce infection levels. These measures will help recovering the individual's oral health because oral flora will be balanced. However, successful management requires not only OES, but also remineralization of the tooth structure and restorative interventions when necessary. It is also extremely important that the individual recognizes the problem (17). The patients must be motivated and compliant, contributing to the success of all measures adopted, increasing their quality of life.

Mass excavation of carious lesions with the removal of infected and disorganized dentin and temporary sealing of the resulting cavities with glass ionomer cements not only contribute to OES, but also make possible the remineralization of dentin adjacent and subjacent to the temporary restoration, interrupting the metabolic cycle of remaining bacteria with the oral environment and arresting caries progression. It is known that the more fluoride-releasing restorative materials are used, the more fluoride reservoirs will exist in oral environment, which contributes to reduce $S$. mutans counts when compared with the use of non-fluoridereleasing materials (18).

Using the agar diffusion test, Da Silva et al. (19) evaluated the antimicrobial effect of glass ionomer cements against $S$. mutans, S. sobrinus, L. acidophilus and $A$. viscosus. The authors concluded that fresh and set Vidrion $\mathrm{R}$ presents in vitro antimicrobial activity and releases higher concentrations of fluoride, which can influence the antibacterial activity observed. Silva et al. (20) also highlighted the action of Vidrion R and its importance in clinical studies that confirm in vitro findings to establish the real efficacy of these materials under different conditions present in the oral cavity. As mentioned in the literature $(19,20)$, it was observed that Vidrion R, used for sealing of carious cavities after mass excavation, contribute for reducing the numbers of cariogenic microorganisms due to its antimicrobial properties. Moreover, it is a low-cost material that can be easily purchase by public health services.

In conclusion, the findings of this study reinforce that OES is effective in decreasing the number of $S$. mutans CFU present in the saliva of high-caries-risk pregnant women.

\section{RESUMO}

O objetivo desta pesquisa foi determinar o efeito da adequação do meio bucal sobre a contagem de Streptococcus mutans em gestantes de alto risco à cárie, participantes de um programa de prevenção em uma instituição de ensino público, antes e após adequação do meio bucal. Amostras de saliva de 30 gestantes (18 a 43 anos) que procuraram atendimento na Clínica de Odontologia Preventiva da FOAr-UNESP foram coletadas antes e após procedimentos de adequação do meio bucal, e examinadas para observação e contagem das UFCs de $S$. mutans. Foi demonstrado que houve diminuição na quantidade das UFCs $(p<0,0001)$ entre as amostras. Em relação à faixa etária, $70,0 \%$ das gestantes tinham entre 18 e 30 anos de idade e $30,0 \%$ pertenciam à faixa etária de 31 a 43 anos. Dados relativos ao período da gestação revelaram que $73,4 \%$ estavam no $2^{\circ}$ trimestre e $13,3 \%$ estavam igualitariamente no $1^{\circ}$ e $3^{\circ}$ trimestres. A adequação do meio bucal se mostrou eficaz na diminuição das UFCs de $S$. mutans presentes na saliva de gestantes de alto risco de cárie. Este procedimento é simples e extremamente efetivo, atendendo às necessidades de tratamento básico de gestantes que procuram atendimento odontológico no serviço público de saúde.

\section{ACKNOWLEDGEMENTS}

The authors wish to thank FUNDUNESP (Grant \#01374/04) for the financial support.

\section{REFERENCES}

1. Keyes PH. The infections and transmissible nature of experimental dental caries. Arch Oral Biol 1960;29:453-460.

2. Caufield PW, Dasanayake AP, Li Y, Pan Y, Hsu J, Hardin JM Natural history of Streptococcus sanguinis in the oral cavity of infants: evidence for a discrete window of infectivity. Infect Immun 2000;68:4018-4023.

3. Hanada N. Current understanding of the cause of dental caries. Jpn $\mathrm{J}$ Infect Dis 2000;53:1-5.

4. Bentley C, Crawford JG, Broderius CA. Analytical and physiological variability of salivary microbial counts. J Dent 
Res1998;67:1409-1413.

5. Reich E, Lussi A, Newbrun E. Caries risk assessment. Int Dent J 1999;1:15-26.

6. Davey AL, Rogers AH. Multiple types of the bacterium Streptococcus mutans in the human mouth and their intra-family transmission. Arch Oral Biol 1984;29:453-460.

7. Van Palenstein-Helderman WH, Ijsseldijk M, Huis in't Veld JHJ. A selective medium for the two major subgroups of the bacterium Streptococcus mutans isolated from human dental plaque and saliva. Arch Oral Biol 1983;28:599-603.

8. Gábris K, Nyárasdy I, Bánóczy J. Significance of assessing risk factors for caries in their prevention. Orv Hetil 2002;143:14671473.

9. Herrera GCL, Pantoja FP, La Maza T, Sanhueza CA, Salazar NLA. Microbiologic and molecular diagnostic of cariogenic bacteria in pregnant women from the Araucania Region of Chile. Rev Chilena Infectol 2008;4:270-275.

10. Carletto Körber FP, Cornejo LS, Giménez MG. Early acquisition of Streptococcus mutans for children. Acta Odontol Latinoam 2005;18:69-74.

11. Law V, Seow WK, Townsend G. Factors influencing oral colonization of mutans streptococci in young children. Aust Dent J 2007;52:93-100.

12. Kishi M, Abe A, Kishi K, Ohara-Nemoto Y, Kimura S, Yonemitsu M. Relationship of quantitative salivary levels of Streptococcus mutans and S. sobrinus in mothers to caries status and colonization of mutans streptococci in plaque in their 2.5-year-old children. Community Dent Oral Epidemiol 2009;37:241-249.

13. Meyer K, Geurtsen W, Günay H. An early oral health care program starting during pregnancy: results of a prospective clinical longterm study. Clin Oral Investig 2010;14:257-264.

14. Berkowitz RJ. Mutans streptococci: acquisition and transmission. Pediatr Dent 2006;28:106-109.

15. do Rego MA, Koga-Ito CY, Jorge AO. Effects of oral environment stabilization procedures on counts of Candida spp. in children. Braz Oral Res 2003;17:332-336.

16. Signoretto C, Burlacchini G, Faccioni F, Zanderigo M, Bozzola N, Canepari P. Support for the role of Candida spp. in extensive caries lesions of children. New Microbiol 2009;32:101-107.

17. Meyers IA. Diagnosis and management of the worn dentition: risk management and pre-restorative strategies for the oral and dental environment. Ann R Australas Coll Dent Surg 2008;19:27-30.

18. Duque C, Negrini T de C, Hebling J, Spolidorio DM. Inhibitory activity of glass-ionomer cements on cariogenic bacteria. Oper Dent 2005;30:636-640.

19. da Silva RC, Zuanon AC, Spolidorio DM, Campos JA. Antibacterial activity of four glass ionomer cements used in atraumatic restorative treatment. J Mater Sci Mater Med 2007; 18:1859-1862.

20. Silva RC, Zuanon AC, Esberard RR, Candido MS, Machado JS. In vitro microhardness of glass ionomer cements. J Mater Sci Mater Med 2007;18:139-142. 